\title{
Comparative Education in the Era of Globalisation: evolution, missions and roles
}

\author{
MARK BRAY \\ University of Hong Kong, China
}

\begin{abstract}
Globalisation is a dynamic process which has major implications for many domains of activity. The field of comparative education is one of these domains. Yet this is not just a passive, one-way influence; comparative educationists can themselves promote and shape elements of globalisation. The field of comparative education is arguably more closely related to globalisation than most other fields of academic enquiry. Comparative education is naturally concerned with cross-national analyses, and the field encourages its participants to be outward looking. At the same time, the field responds to globalisation. Cross-national forces of change are reflected in dominant paradigms, methodological approaches, and foci of study. In order to provide a context for subsequent discussion, this article begins by considering some of the meanings of globalisation. The article then turns to the nature of the field of comparative education, noting dimensions of evolution over the decades and centuries. Moving to relatively recent times, the article focuses on the World Council of Comparative Education Societies (WCCES), which was created in 1970 and which currently has 30 constituent societies. As its name suggests, the WCCES is a global body - with all the positive features and tensions that that implies. The article notes some characteristics of the global field of comparative education, while also commenting on distinctive features in some countries and regions. The article highlights some specific domains in which globalisation has changed the agenda in which comparativists can and should work.
\end{abstract}

\section{Globalisation: concepts and debate}

Held et al (1999), presenting one of the most thorough analyses of the nature and impact of globalisation, began their book with the observation (p. 1) that: 
Globalization is an idea whose time has come. From obscure origins in French and American writings in the 1960s, the concept of globalization finds expression today in all the world's major languages.

However, they added that the term lacks precise definition. It is used widely and vaguely, and can mean different things to different people.

At a general level, Held et al suggest $(1999$, p. 2$)$ that globalisation may be thought of as 'the widening, deepening and speeding up of worldwide interconnectedness in all aspects of contemporary social life'. The range of dimensions, Held et al observed, stretch 'from the cultural to the criminal, the financial to the spiritual'. Elsewhere, Held \& McGrew (2000, p. 3) have noted that globalisation:

... has been variously conceived as action at a distance (whereby the actions of social agents in one locale can come to have significant consequences for 'distant others'); time-space compression (referring to the way in which instantaneous electronic communication erodes the constraints of distance and time on social organization and interaction); accelerating interdependence (understood as the intensification of enmeshment among national economies and societies such that events in one country impact directly on others); a shrinking world (the erosion of borders and geographical barriers to socio-economic activity); and, among other concepts, global integration, the reordering of interregional power relations, consciousness of the global condition and the intensification of inter-regional interconnectiveness.

All these dimensions have impact on the field of comparative education as well as on other fields of endeavour.

Nevertheless, interpretations of the precise nature of dynamics depend strongly on the perspectives of the observers. Held et al (1999) distinguished between three broad schools of thought on globalisation:

The hyperglobalists define contemporary globalisation as a new era in which peoples everywhere are subjected to the disciplines of the global marketplace. Emphasising economic forces, this view argues that globalisation is bringing about 'denationalisation' of economies through the establishment of transnational networks of production, trade and finance. In this 'borderless' economy, national governments are 'relegated to little more than transmission belts for global capital or, ultimately, simple intermediate institutions sandwiched between increasingly powerful local, regional and global mechanisms of governance' (Held et al, 1999, p. 3).

The sceptics, by contrast, maintain that contemporary levels of economic interdependence are not historically unprecedented. The nineteenth-century era of the classical Gold Standard, they note, was also a period of economic integration. The sceptics consider the hyperglobalist thesis to be fundamentally flawed and politically naive since it underestimates the enduring power of national governments to regulate international economic activity. The sceptics recognise the economic power of regionalisation in the world economy, but assert that by comparison with the age of world empires, 
the international economy has become considerably less global in its geographical embrace.

The transformationalists, like the hyperglobalists, consider globalisation to be a central driving force behind the rapid social, political and economic changes that are reshaping societies. However, they are less certain of the direction in which trends are leading and about the kind of world order which it might prefigure. For transformationalists, the existence of a single global system is not taken as evidence of global convergence or of the arrival of a single world society. Rather, they argue, 'globalization is associated with new patterns of global stratification in which some states, societies and communities are becoming increasingly enmeshed in the global order while others are becoming increasingly marginalized' (Held et al, 1999, pp. 7-8). The new patterns require reformulation of vocabulary from North/South and First/Third World, recognising that new hierarchies cut across and penetrate all societies and regions of the world.

These remarks show that the concept of globalisation is complex. The term is viewed differently even within particular academic disciplines, and across disciplines the variation increases further. Comparative education is by nature an interdisciplinary field. This provides a valuable meeting point for disciplinary perspectives, but also increases the potential for confusion.

\section{Comparative Education: historical development and evolution}

To place in context subsequent remarks about the contemporary nature of the field and the extent to which it has become globalised, it is useful to sketch some dimensions of its history and evolution. It is commonly asserted (see, for example, Epstein, 1994; Van Daele, 1994) that the origins of comparative education as a clearly defined scholarly activity lie in nineteenth-century France. Specifically, Marc-Antoine Jullien, who in 1817 wrote a work entitled Esquisse et Vues Préliminaires d'un Ouvrage sur l'Éducation Comparée, has been widely described as the 'Father of Comparative Education' (see, for example, Berrio, 1997; Leclerq, 1999). The field is then commonly considered to have spread to other parts of Europe and to the USA, before reaching other regions of the world. An alternative view might be that the field had multiple origins (Halls, 1990; Zhang \& Wang, 1997; Bray \& Gui, 2001); but it is undeniable that significant work was developed in Europe and the USA. Further notable landmarks include the first university-level course in 1899, taught at Teachers College, Columbia, USA (Bereday, 1964a), and a famous 1900 speech by Sir Michael Sadler in the United Kingdom (UK) (Sadler, 1900). During the twentieth century, the field gathered momentum and spread. Nakajima (1916) published a book in Japanese entitled Comparative Study of National Education in Germany, France, Britain and the USA, which was translated into Chinese with some adaptation by Yu (1917). Further early works include Sandiford (1918) and Kandel (1935). 
The extent to which these early works may be considered global deserves some examination. Jullien's (1817) work was explicitly confined to the states of Europe - though that may perhaps already be considered quite a broad canvas for that point in history. Sadler used examples from both Western Europe and North America, and Nakajima (1916) focused on Germany, France, the UK and the USA. Interestingly, although Nakajima's book was written in Japan, it did not include focus on Japan; but Yu's (1917) translation and adaptation did add some material on China. Like Nakajima, Sandiford (1918) and Kandel (1935) focused on Germany, France, the UK and the USA, but Sandiford also included Canada and Denmark, while Kandel included Italy and Russia.

During the second half of the twentieth century, the field blossomed in a spectacular way with the publication of many journals, including:

Comparative Education Review, an English-language journal launched in the USA in 1957;

Comparative Education, another English-language journal launched in the UK in 1964;

Foreign Education Conditions, a Chinese-language publication which was launched as an internal publication in Beijing in 1965, became a full journal in 1980, and was retitled Comparative Education Review in 1992;

Compare: a journal of comparative education, an English-language publication which began in the UK as a newsletter in 1968, and which became a fully established journal in 1977;

Canadian and International Education/Éducation Canadienne et Internationale, which was launched in Canada in 1973 to publish both English-language and French-language articles;

Comparative Education Research, a Japanese-language journal which was launched in 1975;

The Journal of Comparative Education, a Chinese-language publication which began as a newsletter published in Taiwan in 1982 and which in 1997 evolved into a full journal;

Educazione Comparata, an Italian journal which commenced publication in 1990;

Current Issues in Comparative Education, an electronic journal which commenced publication in the USA in 1998.

Other journals used the word 'international' in their titles and also published many comparative articles. In 1931 a journal under the trilingual title of Internationale Zeitschrift für Erziehungswissenschaft, International Education Review 
and Revue Internationale de Pédagogie was launched in Germany and published articles in German, English and French. After a hiatus in the Second World War, it was re-launched in 1947 and proceeded with publication for another 4 years. Another hiatus occurred in 1951, but in 1955 the journal was again relaunched with almost the same original title except that the English name was International Review of Education rather than International Education Review (McIntosh, 2002). In 1971, UNESCO in Paris launched Prospects: quarterly review of education, initially in parallel English and French versions, then from 1973 also in Spanish, and by the 1990s also in Arabic, Chinese and Russian. In 1995, the subtitle of the journal was changed to Quarterly Review of Comparative Education. The English-language International Journal of Educational Development was launched in the UK in 1981, and is also considered a major journal in the field.

To these journals were added many seminal textbooks. Towards the end of the century they became too numerous to list, but significant Englishlanguage works in the decades immediately following the Second World War included Hans (1948), King (1958), Bereday (1964b) and Havighurst (1968). Hans's book to a large extent followed existing geographic traditions, with four case study chapters focusing on England, the USA, France and the USSR, but it did also refer to other countries in all continents. King's work was also dominated by the traditional focus. Like Sandiford's book four decades previously, King had individual chapters on Germany, France, the UK, the USA and Denmark; but whereas Sandiford's sixth country of focus was Canada, King's was India. This reflected the emergence to sovereignty of a group of colonies - a trend that gathered speed in the 1960s and which brought much broader focus to the field of comparative education. Bereday's (1964b) book focused on the traditional USA, England, France and Germany, but also on the USSR, Turkey, Poland and Colombia. Havighurst focused on France, the USSR, Japan, Brazil, China, Ghana, South Africa, New Zealand, the Sudan and the Netherlands, and, with an unusual slant, also included chapters on the Hopi Indians (USA) and Tudor (fifteenth and sixteenthcentury) England. During the next three decades the field further broadened its geographic scope, placing much more emphasis on less-developed countries as well as on industrialised ones, and thus in a sense becoming more globalised.

\section{The WCCES: a global body in comparative education}

The World Council of Comparative Education Societies (WCCES) was formed in 1970, having evolved from an International Committee of Comparative Education Societies which had been convened by Joseph Katz, of the University of British Columbia in Canada, in 1968 (Epstein, 1981, p. 261). Five societies came together to form the Council, namely:

The Comparative \& International Education Society (CIES) of the USA, which had been founded in 1956; 
The Comparative Education Society in Europe (CESE), which had been founded in 1961;

The Japanese Comparative Education Society (JCES), which had been founded in 1964;

The Comparative $\&$ International Education Society of Canada (CIESC), which had been founded in 1967;

The Korean Comparative Education Society (KCES), which had been founded in 1968.

Over the decades, the number of constituent societies in the Council has fluctuated, but in 2002 the WCCES had 30 societies. Of these, 23 were national or sub-national societies (Brazil, Bulgaria, Canada, China, Czech Republic, Cuba, Hong Kong, Germany, Greece, Hungary, India, Israel, Italy, Japan, Korea, Philippines, Poland, Russia, Spain, Taiwan, UK, Ukraine, and USA), five were regional societies (Australia \& New Zealand, Europe, Nordic countries, Southern Africa, and Asia), and two were language-based societies (French and Dutch).

While the total list of constituent societies was impressive, in some countries and regions the societies have been fragile. The organisations have depended on the enthusiasm of a few individuals, and have commonly operated on a voluntary basis with low budgets. The fragility can be illustrated by comparing the 2002 WCCES list of constituent societies with that for 1993. In 1993, the WCCES had 31 constituent societies, but only 25 were still on the list in 2002 because six had ceased to exist. These were:

Asociación Argentina de Educación Comparada (AAEC);

Asociación Colombiana de Educación Comparada (ACEC);

Egyptian Group for Comparative Education (EGCE);

London Association of Comparative Education (LACE);

Nigerian Comparative Education Society (NCES);

Portuguese Comparative Education Society (PCES).

However, five new societies had joined the list, namely:

Asociación de Pedagogos de Cuba (Sección de Educación Comparada)

(APC-SEC);

Comparative Education Society of Asia (CESA);

Comparative Education Society of Hong Kong (CESHK);

Comparative Education Society of the Philippines (CESP);

Ukraine Council for Comparative Education (UCCE).

Also, a new Argentinean group had formed and had expressed intention to apply for admission to the Council; a parallel group had been formed in Venezuela; and in France a body had been created under the title Association pour le Développement des Échanges Internationales et de la Comparaison en Éducation (ADECE). 
The most obvious activities of the WCCES have been the organisation of periodic World Congresses of Comparative Education. The first Congress was held in Canada in 1970, and was followed by ones in Switzerland (1974), United Kingdom (1977), Japan (1980), France (1984), Brazil (1997), Canada (1989), Czechoslovakia (1992), Australia (1996), South Africa (1998), and South Korea (2001). In 2002 it was decided that the next would be held in Cuba in 2004.

Other WCCES activities include advocacy for the field. The WCCES is affiliated to UNESCO as a Non-governmental Organisation (NGO), and makes official representations to the international community through that body. The WCCES also operates a web site (http://www.hku.hk/cerc/wcces), which contains links to organisations and educational institutions related to the field. One part of that web site connects readers to Ministries of Education in over 120 different countries.

Like all such global bodies, however, the WCCES has constraints in its operation. As noted by King (1997, p. 81)

In all academic circles there are prima donnas and factions, and in a world society of members from so many traditions and contexts it is often difficult to reconcile the diversity of interests and priorities. There are also diplomatic difficulties in finding acceptable venues which are also convenient for the gathering-in of colleagues from all over the world.

The WCCES statutes do not declare any official language, but most WCCES affairs are conducted in the English language. English has gained dominance as an international language, but this is not a neutral form of globalisation. By convention, arising from the fact that the original Secretariats were located in Ottawa (Canada) and then Geneva (Switzerland), French has also been a permitted language for communication for the WCCES. During the last decade, however, French has been little more than a token vehicle for official deliberation of WCCES affairs. The WCCES Officers are very aware of the imbalances that can be associated with language, and welcome suggestions on ways to promote the field of comparative education in multiple languages.

Another bias arises from the geographic spread of WCCES member societies. Although the WCCES has constituent societies in every continent, and has also held Congresses in every continent, several parts of the world do not have direct representation in the Council. Thus in 2002, following the demise of the Nigerian and Egyptian societies, the only African society was that serving Southern Africa. South America was represented only by Brazil; and the Arab states were not represented at all. By contrast, Europe and Asia were well represented.

Nevertheless, the WCCES may certainly be considered a global body; and in many respects it is also globalising. It brings together scholars from different parts of the world for exchange of ideas, and promotes joint projects. Certainly a great deal more can be done to facilitate the development of comparative education in different regions of the world and to promote the 
global dimensions of the field; but the WCCES does at least provide one vehicle to do this.

\section{Paradigms, Methods and Foci in Comparative Education}

The field of comparative education, at least in some parts of the world, has drawn strongly on the theoretical bases of the social sciences. To some extent, therefore, shifts in dominant paradigms within the social sciences have been reflected in shifts in the field of comparative education. This includes the rise of positivism in the 1960s and 1970s, and the popularity of postmodernism in the 1980s and 1990s (Psacharopoulos, 1990; Epstein, 1994; Crossley, 2000; Paulston, 2000). However, comparative education scholars have tended to use a fairly limited set of tools from the social sciences. Books and journal articles display many commentaries based on literature reviews, but relatively few studies based on survey research, and almost no studies based on experimental methods.

In order to gain deeper understanding of this phenomenon, Rust et al (1999) analysed articles in three major English-language journals in the field, namely Comparative Education Review published in the USA, Comparative Education published in the UK, and the International Journal of Educational Development published in the UK. Reviewing articles in the 1960s, they found (p. 100) that $48.5 \%$ were mainly based on literature review and $15.2 \%$ were historical studies. For the 1980s and 1990s, Rust et al found a marked drop in the two categories - to $25.7 \%$ mainly based on literature review, and $5.0 \%$ historical studies. Reviews of projects had increased, as had participant observation and research based on interviews and questionnaires. In this respect, the field had increased its use of some standard social science instruments.

Rust et al also scrutinised the qualitative/quantitative biases of the articles. Their survey of 427 articles published in 1985, 1987, 1989, 1991, 1993 and 1995 found that $71.2 \%$ were based on qualitative methods, $17.3 \%$ were based on quantitative methods, $10.8 \%$ were based on a combination of qualitative and quantitative, and $0.3 \%$ were based on other strategies. Commenting on this, Rust et al suggested (1999, p. 106) that scholars in the field of comparative education:

... tend to rely on similar philosophical assumptions. Concerning the nature of reality, comparative educators would tend to see reality as somewhat subjective and multiple, rather than objective and singular. Epistemologically, comparative educators would tend to interact with that being researched rather than acting independently and in a detached manner from the content. Axiologically, comparative educators would tend not to see research as value free and unbiased; rather, they would accept the notion that their research is value laden and includes the biases of the researcher. 
A third aspect of the study by Rust et al concerned the geographic foci of the articles. During the 1960s, the dominant focus was on high-humandevelopment countries (using the classification of the United Nations Development Programme). By the 1980s/1990s, however, the balance had shifted significantly. It still showed bias towards these countries, but included a much greater focus on low-human-development countries. Thus, whereas in the 1960 s $73.1 \%$ of the articles in Comparative Education Review and Comparative Education focused on high-human-development countries, and $15.0 \%$ focused on low-human-development countries, in the 1980s/1990s these proportions were 43.1 and $23.3 \%$.

However, the nature of the themes and the methodological approaches have been very different in different parts of the world at particular periods in history. Thus, although Rust et al (1999) referred throughout their article to 'the field' of comparative education, their analysis focused only on Englishlanguage journals, and only on ones published in the USA and UK. Cowen (2000, p. 333) has highlighted the coexistence of multiple comparative educations. His observation on the one hand applies to different groups within particular countries who have different methodological approaches and domains of enquiry, and who may or may not communicate with each other. It also applies to groups in different countries who operate in different languages with different scholarly traditions, and who also may or may not communicate with counterparts in other countries and language groups.

Concerning the differences in scholarly traditions in different countries, it is instructive to compare the work of Harold Noah and Max Eckstein during the three decades from the mid 1970s with that of Gu Mingyuan. Sets of collected works by these authors have been published by the Comparative Education Research Centre at the University of Hong Kong, and thus may easily be placed side by side (Noah \& Eckstein, 1998; Gu, 2001). Among the major concerns of Noah and Eckstein, who were based in the USA and who operated mainly in the English-speaking arena, were methodological issues in the positivist framework and oriented to First World concerns. Gu, by contrast, operated mainly in the Russian and Chinese-speaking arenas. His writings, particularly during the early part of his career, were couched within a Marxist-Leninist framework, and he was especially concerned with the lessons that China could learn from industrialised countries. Especially during the 1970s and 1980s, the comparative education world in which Gu lived was a very different environment from that in which Noah and Eckstein lived.

During the 1990s, however, these two worlds showed some signs of convergence. As China opened up, and as English became more widespread, scholars in China paid more attention to the literatures and methodological approaches in Western countries. Academic interchange between the two cultures increased, facilitated by translations of English-language books into Chinese and by cross-national visits by both sides. It is arguable that the flow of ideas from the opening up was unbalanced: Chinese scholars were influenced by Western traditions much more than Western scholars were 
influenced by Chinese traditions, and the number of books translated from Chinese to English was considerably smaller than the number translated from English to Chinese. However, some Western scholars have certainly explored Chinese academic traditions in depth, and have gained from doing so. In this context, the work of Ruth Hayhoe (e.g. 1999, 2001) immediately comes to mind.

The 1990s and initial years of the present century have also brought some broadening of geographic interest among the different scholarly communities. Throughout their histories, albeit growing over time, the major English-language journals listed at the beginning of this article have contained a significant number of articles on the less-developed countries of Africa, Asia and Latin America in addition to work on Western Europe, North America and Australasia. In China, the volume of scholarly analysis of education in lessdeveloped countries has been much more modest. This has partly reflected priorities, insofar as policy makers have felt that less can be learned from poor countries than from prosperous ones. It has also reflected the fact that although overseas Chinese communities exist in many parts of the world, China has had fewer political and cultural links with Africa, Western Asia and Latin America. Nevertheless, some broadening of geographic interest has been evident in Chinese-language publications, both in the mainland and in Taiwan (Yung, 1998; Lee, 1999).

Despite these observations about convergence, however, it remains the case that the topics chosen for comparative analysis, and the methodological approaches, have continued to vary considerably in different parts of the world. Gender, for example, has been a much stronger topic for focus in Western countries than in Asian societies; and analyses of the World Bank and other international agencies have been much more common in the Englishlanguage journals than in the Chinese, Japanese or Korean journals. Similarly, not all societies have been equally interested in themes of postcolonialism, multiculturalism and civil strife. Thus, while it is increasingly possible to talk of about a global field of comparative education, it is necessary to recognise continued variations.

\section{Missions and Roles in the Era of Globalisation}

Crossley $(1999,2000)$ and Watson (2001) have presented insightful analyses of the field of comparative education at the turn of the century, and have stressed the need for reconceptualisation. The forces of globalisation, they suggest, provide both an imperative and an opportunity. The imperative arises from the changed environment brought by globalisation, and the opportunity arises from the increased interest in international affairs among academics, policy makers and practitioners. The field of comparative education, they argue, can be revitalised and can secure fresh relevance within the new environment.

Various other scholars have also noted ways in which the field of comparative education can grapple with issues of globalisation. They include 
Sanz (1998), Burbules \& Torres (2000), Tickly (2001), Welch (2001) and Carnoy \& Rhoten (2002). Particularly useful to the present article is the work of Marginson \& Mollis (2001, pp. 611-614), who presented five implications of globalisation for a reforged comparative education. These implications may be summarised as follows:

1. Analytical frameworks. Scholars should locate nation-to-nation comparisons in wider frameworks. At the same time, they should note that global effects are contested and uneven, and vary among nations, regions and institutions. Important work by comparativists has already been conducted along these lines, but more is needed.

2. Units of analysis. The traditional comparative map of the world, in which all nations are formally similar and ranked according to their level of development on a single scale, is more inadequate than ever. It fails to explain power relations between nations, and it hides qualitative national differences. Globalisation requires 'a new geopolitical cartography that traces the flows of global effects and the patterns of imitation, difference, domination, and subordination in education policy and practice' (Marginson \& Mollis, 2001, p. 612).

3. Focus on cross-border international education. Cross-border trade in international education has become an important object of research in itself. Such trade raises questions about the identities of mobile students, and about the attributes required for educators, institutions and systems. Sub-themes include tensions between pedagogical practices and national cultures, and the mushrooming of on-line education communities.

4. Forms of Identity. Globalisation opens up a new potential for forms of identity other than national identity. The traditional focus on the nation-state downplayed supranational cultural and religious identities, and obscured intranational regional variety in educational participation, resourcing and outcomes.

5. The Impact of Globalisation at the National Level. Modern education systems are still organised locally and nationally, and are still subject to national regulation. The trends of increased mobility and cosmopolitanism, Marginson \& Mollis suggest (p. 613), have major implications for policies on the preparation of citizens in education. Further research is also needed on the extent to which international agencies and others shape national education policies.

No doubt this list could be extended. It is, however, a useful starting point to show that comparative education can and should play a very different role in the era of globalisation. It should address new questions, and it should be reinvigorated as a vehicle to assist academics and practitioners to understand the changes around them. This is not to say that the nation-state should be discarded as a unit of analysis, but that an expanding agenda could focus on wider issues which impact on education within individual countries. 


\section{Conclusions}

This article commenced by noting that the field of comparative education is arguably more closely related to globalisation than most other fields of academic enquiry. One major factor is that comparative education is naturally concerned with cross-national analyses, and by its very nature encourages its participants to be outward looking. At the same time, the article has pointed out that the field of comparative education is shaped by globalisation. Crossnational forces of change are reflected in dominant paradigms, methodological approaches, and foci of study. Reviewing the history of the field, the article has noted that comparative scholars have become much more global in their approaches than used to be the case.

The first part of this article quoted the observation by Held et al (1999, p. 2) that globalisation may be thought of as the widening, deepening and speeding up of worldwide interconnectedness in all aspects of contemporary social life'. Along similar lines, Delanty (2000, p. 81) refers to 'the diminishing importance of geographical constraints', and has described globalisation as 'the deterritorialization of space'. These phenomena have certainly been seen in the field of comparative education. As noted by Wilson (2003), whereas early scholars had to rely on the printed word and on slow communications through the postal system and other mechanisms, their contemporary counterparts can access the Internet and liaise inexpensively by email. Further, reductions in the cost of air travel have facilitated face-to-face contact with colleagues and cultures in a way that was unimaginable in former decades. Time-space compression and improved access to people, places and societies have assisted the field to develop in important ways.

Among the institutions which promote globalisation are the various national, regional and language-based comparative education societies and the global body which brings them together, the World Council of Comparative Education Societies (WCCES). Most of the national, regional and languagebased societies hold annual and biennial conferences which attract participants from outside the countries, regions and language groups which the societies mainly serve; and every few years the WCCES organises a World Congress of Comparative Education. These events increase the interflow and promote internationalisation. However, imbalances in access remain, and comparative education is certainly not yet (and is unlikely ever to become) a homogeneous field to which scholars from all countries and language groups have equal access.

Within the field, globalisation has itself become an important topic for study and has affected the nature of discourse. For many scholars the nationstate remains a favoured unit for analysis, but an increasing number of studies draw instructively on multi-level analysis (Bray \& Thomas, 1995; Alexander, 2000; Crossley, 2000). Multi-level studies can show how global forces do or do not shape patterns within particular countries, provinces, districts, institutions and even classrooms. The field of comparative education contains some hyperglobalists who, like their counterparts in other fields, argue that the 
world is becoming borderless and that national governments, using the words quoted above from Held et al $(1999$, p. 3) are 'relegated to little more than transmission belts for global capital'. However, scholars with this perception are a minority in the field. The majority recognise that cross-national forces exist and that in some ways they have become stronger than in the past, but point out that cross-national forces have long been an important influence on education systems and that national governments still retain major roles in the education sector.

It would be unrealistic to assert that the field of comparative education will ever reach unanimity in perspectives on globalisation. One obstacle is that, as noted above, the term itself is viewed differently even within particular disciplines; and across disciplines the variation increases further. Since by nature comparative education is an interdisciplinary field, the potential for common conceptions seems very limited.

Nevertheless, the field of comparative education can contribute to one important agenda identified by Held et al (1999, pp. 7-8), namely analysis of the extent to which globalisation is associated with new patterns of stratification in which some states, societies and communities are increasingly enmeshed in the global order while others are increasingly marginalised. This theme again underlines the value of multilevel analysis which identifies the impact of supra-national, national and sub-national forces on education systems. Such frameworks address what Arnove \& Torres (1999) call the dialect of the global and the local. Issues of marginalisation have been specifically highlighted by specialists in comparative education within the context of globalisation (see, for example, Stromquist, 2002). Such work can contribute to broader, multidisciplinary analysis beyond that specifically concerned with education.

\section{Note}

This article has also been published in the Revista Española de Educación Comprada, No. 8, 2002. Permission to reproduce the article here is gratefully acknowledged.

\section{Correspondence}

Mark Bray, Comparative Education Research Centre, Faculty of Education, University of Hong Kong, Pokfulam Road, Hong Kong, China (mbray@hku.hk).

\section{References}

Alexander, Robin (2000) Culture and Pedagogy: international comparisons in primary education. Oxford: Blackwell. 
Arnove, Robert \& Torres, Carlos Alberto (1999) Comparative Education: the dialectic of the global and the local. Lanham: Rowman \& Littlefield.

Bereday, George Z.F. (1964a) James Russell's Syllabus of the First Academic Course in Comparative Education, Comparative Education Review, 7, pp.189-196.

Bereday, George Z.F. (1964b) Comparative Method in Education. New York: Holt, Rinehart \& Winston.

Berrio, Julio Ruiz (1997) Presentación, Revista Española de Educación Comparada, 3, pp. 7-11. Special Issue on Concepto, Métodos y Técnicas en Educación Comparada: homenaje a Jullien de París en el 150 aniversario de su fallecimiento.

Bray, Mark \& Gui, Qin (2001) Comparative Education in Greater China: contexts, characteristics, contrasts, and contributions, Comparative Education, 37, pp. 451-473.

Bray, Mark \& Thomas, R. Murray (1995) Levels of Comparison in Educational Studies: different insights from different literatures and the value of multilevel analyses, Harvard Educational Review, 65(3), pp. 472-490.

Burbules, Nicholas C. \& Torres, Carlos Alberto (Eds) (2000) Globalization and Education: critical perspectives. New York: Routledge.

Carnoy, Martin \& Rhoten, Diana (2002) What does Globalization Mean for Educational Change? A comparative approach, Comparative Education Review, 46, pp. 1-9.

Cowen, Robert (2000) Comparing Futures or Comparing Pasts?, Comparative Education, 36, pp. 333-342.

Crossley, Michael (1999) Reconceptualising Comparative and International Education, Compare: a journal of comparative education, 29, pp. 249-267.

Crossley, Michael (2000) Bridging Cultures and Traditions in the Reconceptualisation of Comparative and International Education, Comparative Education, 36, pp. 319-332.

Delanty, Gerard (2000) Citizenship in a Global Age: society, culture, politics. Buckingham: Open University Press.

Epstein, Erwin H. (1981) Toward the Internationalization of Comparative Education: a report on the World Council of Comparative Education Societies, Comparative Education Review, 25, pp. 261-271.

Epstein, Erwin H. (1994) Comparative and International Education: overview and historical development, in Torsten Husén \& T. Neville Postlethwaite (Eds) The International Encyclopedia of Education, 2nd Edn, pp. 918-923. Oxford: Pergamon Press.

Gu Mingyuan (2001) Education in China and Abroad: perspectives from a lifetime in comparative education. Hong Kong: Comparative Education Research Centre, The University of Hong Kong.

Halls, W.D. (Ed.) (1990) Comparative Education: contemporary issues and trends. London: Jessica Kingsley.

Hans, Nicholas (1948) Comparative Education: a study of educational factors and traditions. London: Routledge \& Kegan Paul.

Havighurst, Robert J. (Ed.) (1968) Comparative Perspectives on Education. Boston: Little, Brown \& Co.

Hayhoe, Ruth (1999) China’s Universities 1895-1995: a century of cultural conflict. Hong Kong: Comparative Education Research Centre, The University of Hong Kong. 
Hayhoe, Ruth (2001) Lessons from the Chinese Academy, in Ruth Hayhoe \& Julia Pan (Eds) Knowledge Across Cultures: a contribution to dialogue among civilizations, pp. 323-347. Hong Kong: Comparative Education Research Centre, The University of Hong Kong.

Held, David \& McGrew, Anthony (2000) The Great Globalization Debate: an introduction, in David Held \& Anthony McGrew (Eds) The Global Transformations Reader: an introduction to the globalization debate, pp.1-45. Cambridge, Polity Press.

Held, D., McGrew, A., Goldblatt, D. \& Perraton, J. (1999) Global Transformations: politics, economics and culture. Cambridge: Polity Press.

Jullien, Marc-Antoine (1817) Esquisse et Vues Préliminaires d’un Ouvrage sur l'Éducation Comparée. Paris: Société Établie à Paris pour l'Amélioration de l'Enseignement Élémentaire. Reprinted in 1962: Geneva: Bureau International d'Éducation.

Kandel, Isaac Leon (1935) Studies in Comparative Education. London: George G. Harrap.

King, Edmund J. (1958) Other Schools and Ours. New York: Rinehart \& Co.

King, Edmund J. (1997) A Turning-point in Comparative Education: retrospect and prospect, in C. Kodron B. von Kopp, U. Lauterbach, U. Schäfer \& G. Schmidt (Eds) Vergleichende Erziehungswissenschaft: Herausforderung, Vermittlung, Praxis. Festchrift für Wolfgang Mitter zum 70 Geburtstag, pp.81-90. Cologne: Bohlau.

Leclerq, Jean-Michel (Ed.) (1999) Première Partie: Marc-Antoine Jullien de Paris, d'hier à aujourd'hui, in L'Éducation Compareé: mondialisation et spécificités francophones, pp.11103. Paris and Sèvres: Association Francophone d'Éducation Comparée and Centre National de Documentation Pédagogique.

Lee Fung-Jihu, Eric (1999) Comparative Education in Taiwan: retrospect and prospect, in Yang Shen-Kang (Ed.) Educational Sciences: internationalization and indigenisation, pp. 431-471. Taipei: Yang-Chih Book Co. [In Chinese]

Marginson, Simon \& Mollis, Marcela (2001) 'The Door Opens and the Tiger Leaps': theories and reflexivities of comparative education for a global millennium, Comparative Education Review, 45(4), pp. 581-615.

McIntosh, Christopher (2002) International Review of Education: a journal of many incarnations, International Review of Education, 48, pp. 1-20.

Nakajima, Nanjiro (1916) Comparative Study of National Education in Germany, France, Britain and the USA. Tokyo: Kyouiku-shicho Kenkyukai. [In Japanese]

Noah, Harold J. \& Eckstein, Max A. (1998) Doing Comparative Education: three decades of collaboration. Hong Kong: Comparative Education Research Centre, The University of Hong Kong.

Paulston, Rolland G. (Ed.) (2000) Social Cartography: mapping ways of seeing social and educational change. New York: Garland.

Psacharopoulos, George (1990) Comparative Education: from theory to practice, or are you $\mathrm{A}: \backslash$ neo. ${ }^{\star}$ or $\mathrm{B}: \backslash^{\star}$.ist?, Comparative Education Review, 34, pp. 369-380.

Rust, V.D., Soumaré, A., Pescador, O. \& Shibuya, M. (1999) Research Strategies in Comparative Education, Comparative Education Review, 43, pp. 86-109.

Sadler, Sir Michael (1900) How Can We Learn Anything of Practical Value from the Study of Foreign Systems of Education?, reprinted in 1964 in Comparative Education Review, 7, pp. 307-314.

Sandiford, Peter (Ed.) (1918) Comparative Education: studies of the educational systems of six modern nations. London: J.M. Dent and Sons. 
Sanz, Florentino (1998) Perspectivas de la Educación de Adultos en Una Sociedad Globalizada, Revista Española de Educación Comparada, 4, pp. 69-100.

Stromquist, Nelly P. (2002) Globalization, the I, and the Other, Current Issues in Comparative Education, 4(2).

Tickly, Leon (2001) Globalisation and Education in the Postcolonial World: towards a conceptual framework, Comparative Education, 37, pp. 151-171.

Van Daele, Henk (1993) L’Éducation Comparée. Paris: Presses Universitaires de France.

Watson, Keith (2001) Comparative Education Research: the need for reconceptualisation and fresh insights, in Keith Watson (Ed.) Doing Comparative Education Research: issues and problems, pp. 23-42. Oxford: Symposium.

Welch, Anthony R. (2001) Globalisation, Post-modernity and the State: comparative education facing the third millennium, Comparative Education, 37, pp. 475-492.

Wilson, David N. (2003) The Future of Comparative and International Education in a Globalised World, in Bray, Mark (Ed.) Comparative Education: continuing traditions, new challenges, and new paradigms, pp. 15-33. Dordrecht: Kluwer

Yu, Ji (Translator and Editor) (1917) Comparative Study of National Education in Germany, France, Britain and the USA. Shanghai: China Book Company. [In Chinese]

Yung, Cindy S.S. (1998) A Comparison of Comparisons in the Field of Comparative Education: a content analysis of English-medium and Chinese-medium journals. M.Ed. dissertation. Hong Kong: The University of Hong Kong.

Zhang, Ruifan \& Wang, Chengxu (Eds) (1997) Short History of Comparative Studies of Chinese and Foreign Education. Three volumes. Jinan: Shandong Education Press. [In Chinese] 